\title{
THERMAL BEHAVIOUR OF SOME PHARMACEUTICAL PRODUCTS CONTAINING IRBESARTAN, COMPARING TO THE ACTIVE SUBSTANCE
}

\author{
IOANA CRISTINA TIȚA ${ }^{1}$, ELEONORA MARIAN ${ }^{2}$, BOGDAN TIȚA $^{3 *}$, CLAUDIA CRINA \\ TOMA $^{3}$, FELICIA GLIGOR ${ }^{4}$, LAURA VICAȘ ${ }^{1,2}$, EMMA ADRIANA OZON $^{1}$ \\ 1 "Carol Davila” University of Medicine and Pharmacy, Faculty of Pharmacy, 6 Traian Vuia Street, 020956, Bucharest, \\ Romania \\ ${ }^{2}$ University of Oradea, Faculty of Medicine and Pharmacy, Speciality of Pharmacy, 29 Nicolae Jiga Street, 410028, Oradea, \\ Romania \\ 3 “Vasile Goldiș” Western University of Arad, Faculty of Pharmacy, Department of Pharmaceutical Sciences, 86 L. Rebreanu \\ Street, 300041, Arad, Romania \\ 4 “Lucian Blaga” University of Sibiu, 2A Lucian Blaga Street, 550169, Sibiu, Romania
}

*corresponding author: bogdantita@yahoo.com

Manuscript received: December 2018

\begin{abstract}
Thermal analysis is one of the most widely used methods for studying the solid state of pharmaceutical substances. This work reports the study of the thermal behaviour of irbesartan active substance and pharmaceutical products, together with the determination of the melting points by TG, DTG and DSC. The Fourier transformed infrared spectroscopy (FT-IR) and X-ray powder diffractometry (XRPD) were used as complementary techniques. It was observed that the commercial samples showed a different thermal profile than the active substance caused by the presence of excipients and to possible interactions of these with the active substance.
\end{abstract}

\section{Rezumat}

Analiza termică este una dintre cele mai utilizate metode pentru studierea stării solide a substanțelor farmaceutice. Această lucrare prezintă studiul comportamentului termic al substanței active irbesartan și al produșilor farmaceutici, împreună cu determinarea punctelor de topire cu ajutorul metdelor TG, DTG și DSC. Spectroscopia cu infraroșu cu transformată Fourier (FT-IR) și difractometria cu raze X (XRPD) au fost utilizate ca tehnici complementare. S-a observat că produsele comericale au prezentat un profil termic diferit față de substanța activă datorită prezenței excipienților și posibilelor interacțiuni ale acestora cu substanța activă.

Keywords: irbesartan, active substance, pharmaceutical product, thermal analysis, TG, DTG, DSC, FT-IR, XRPD

\section{Introduction}

Essential arterial hypertension is a major cause of morbidity and mortality, which affects approximately 1 billion people worldwide $[1,17]$.

Irbesartan (2-butyl-3-(\{4-[2-(2H-1,2,3,4-tetrazol-5yl)phenyl]phenyl \}methyl)-1,3-diazaspiro [4,4]non-1en-4-one) has the empirical formula $\mathrm{C}_{25} \mathrm{H}_{28} \mathrm{~N}_{6} \mathrm{O}$ and a molecular mass of $428.5 \mathrm{~g} / \mathrm{mol}$. The drug displays low bioavailability related to its poor water solubility $[5,6]$. Irbesartan is an angiotensin II inhibitor, thus preventing the conversion of angiotensin I to angiotensin II. It is a new angiotensin antagonist that has a long duration of action and can be used in the clinical treatment of high blood pressure and heart failure, which could increase the threshold of ventricular fibrillation during ischemia and reduce the incidence of ventricular tachycardia and ventricular fibrillation of myocardial ischemia. Angiotensin II may induce cardiomyocyte hypertrophy and significantly reduce the expression of $\mathrm{Cx} 43$, which may be related to cell cycle change during myocardial hypertrophy. Irbesartan may affect the expression and distribution of $\mathrm{Cx} 43$ and thus improve cardiac muscle tissue damage. Therefore, the effect of irbesartan on Cx43 expression and the mechanism of ventricular arrhythmias caused by myocardial ischemia are of clinical significance [3, $4,7,9,12,16,19,25]$.

Thermal analysis is the term used for analytical methods that study the behaviour of a substance that is subjected to a temperature regime.

Thermal methods of analysis are of great importance for solving pharmaceutical problems such as purity determination, qualitative and quantitative analysis of drugs, determination of thermal stability and kinetic parameters $[11,15,26]$.

Thermogravimetric (TG) analysis and differential scanning calorimetry (DSC) are used in the pharmaceutical 
industry to determine the purity of active substances $[8$, $18]$.

Thermal instability of drugs affects the process of making tablets, the therapeutic efficacy, the toxicity and bioavailability $[2,13,14]$.

In other articles in the literature, the role of thermal methods in the study of the stability and compatibility of different substances used in the manufacture of pharmaceutical forms is presented [10, 20-24].

The literature does not provide data on the behaviour of irbesartan as a pharmaceutical during storage. The purpose of this paper is to study comparatively the thermal behaviour of irbesartan - active substance with several pharmaceutical products containing this substance.

\section{Materials and Methods}

Materials and methods. The substances examined by thermal analysis, FT-IR spectroscopy and X-ray analysis were irbesartan - active substance (I-AS) and four pharmaceutical products (P1, P2, P3, P4) The active substance was obtained from Polisano Pharma SRL, Romania, as pure compound, able to be used for pharmaceutical purposes. The drugs analysed were commercial products, containing different excipients. Thermal analysis. The TG/DTG and DTA curves were recorded using a Netzsch-STA 449 TG/DTA instrument in the temperature range $20-1000^{\circ} \mathrm{C}$, under a dynamic atmosphere of nitrogen $(20 \mathrm{~mL} / \mathrm{min})$ and at a heating rate $(\beta) 10^{\circ} \mathrm{C} / \mathrm{min}$, using platinum crucibles and weighed $\approx 20 \mathrm{mg}$ of samples.

Fourier transformed infrared spectroscopy (FT-IR) and $X$-ray diffraction. FT-IR spectra were recorded on a Shimadzu Prestige-21 apparatus using $\mathrm{KBr}$ discs in the range $4000-400 \mathrm{~cm}^{-1}$. X-ray diffraction patterns (XRPD) were obtained with a Rigaku Ultima IV diffractometer $\left(\mathrm{Cu}_{\mathrm{K} \alpha}\right.$ radiation $)$.

\section{Results and Discussion}

Thermal behaviour

The thermoanalytical curves for the studied compounds, obtained under dynamic temperature conditions at heating rate $(\beta)$ of $10^{\circ} \mathrm{C} / \mathrm{min}$ and a nitrogen atmosphere, are presented in Figures 1-5.

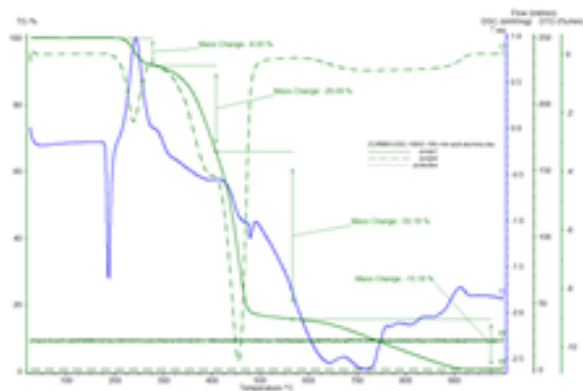

Figure 1.

TG/DTG and DSC curves of I-AS

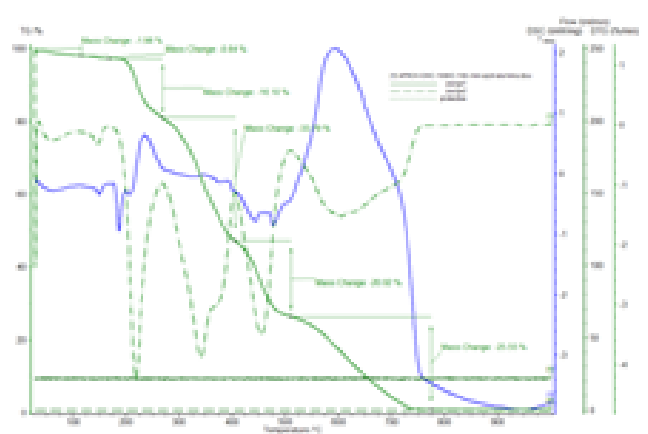

Figure 2.

TG/DTG and DSC curves of P1

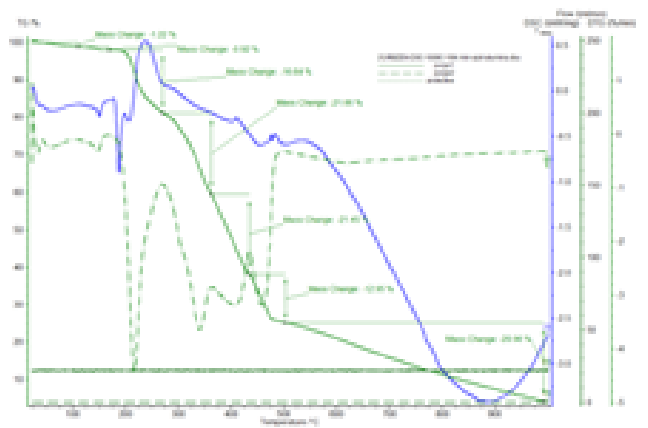

Figure 3.

TG/DTG and DSC curves of P2

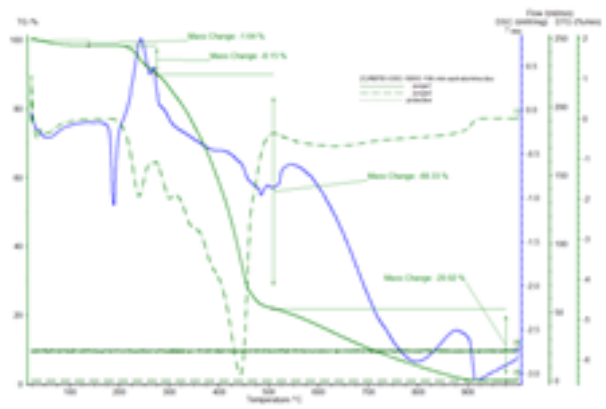

Figure 4.

TG/DTG and DSC curves of P3

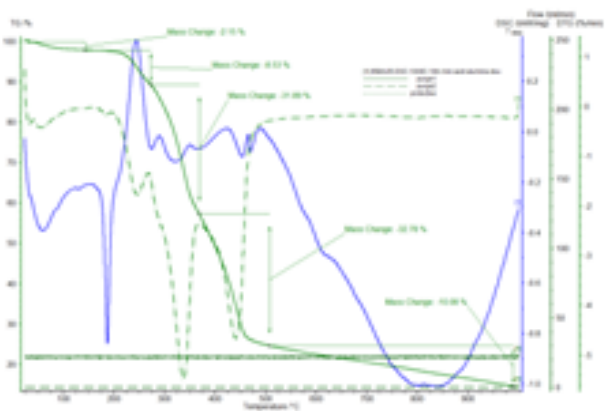

Figure 5.

TG/DTG and DSC curves of P4

The main observations are summarized in Table I. 
Table I

Characteristics of the thermal behaviour for the studied compounds

\begin{tabular}{|c|c|c|c|c|}
\hline Sample & Range of mass loss, ${ }^{\circ} \mathrm{C}$ & Maximum of DTG, ${ }^{\circ} \mathrm{C}$ & Maximum of DSC, ${ }^{\circ} \mathrm{C}$ & Mass loss, $\Delta \mathrm{m} \%$ \\
\hline \multirow{5}{*}{ I-AS } & & & 187.7 & fusion \\
\hline & $192.7-280.7$ & 238.5 & 243.1 exo & 8.00 \\
\hline & $280.8-415.4$ & 397.2 & 397.2 & 26.2 \\
\hline & $415.4-547.6$ & 459.2 & 484.6 & 50.2 \\
\hline & $547.6-919.2$ & $700.0 ; 818.5$ & $642.2 ; 715.1 ; 920.8$ & 15.6 \\
\hline \multirow{7}{*}{$\mathrm{P} 1$} & $25.0-113.1$ & 63.8 & 63.8 & 1.10 \\
\hline & $113.1-169.2$ & 146.2 & 150.0 & 1.10 \\
\hline & & & 189.2 & fusion \\
\hline & $200.0-265.4$ & 215.4 & 235.4 exo & 16.1 \\
\hline & $265.4-407.7$ & 341.5 & 342.7 exo & 34.5 \\
\hline & $407.7-513.8$ & 455.4 & $440.8 ; 475.0$ & 21.1 \\
\hline & $513.8-763.1$ & 607.7 & 593.1 ехо & 26.1 \\
\hline \multirow{8}{*}{$\mathrm{P} 2$} & $25.0-110.6$ & 63.4 & 63.4 & 1.10 \\
\hline & $110.6-169.2$ & 150.0 & 150.0 & 1.10 \\
\hline & & & 184.6 & fusion \\
\hline & $192.6-274.2$ & 215.4 & $207.7 ; 238.5$ exo & 6.70 \\
\hline & $274.2-366.2$ & 343.8 & - & 22.2 \\
\hline & $366.2-433.8$ & 410.8 & 410.8 exo & 21.1 \\
\hline & $433.8-496.9$ & 457.7 & 457.7 & 12.6 \\
\hline & $496.9-1000.0$ & 687.7 & 886.2 & 21.3 \\
\hline \multirow{5}{*}{ P3 } & $25.0-136.4$ & 53.8 & 54.7 & 1.10 \\
\hline & & & 187.7 & fusion \\
\hline & $194.6-269.2$ & 240.8 & 241.6 exo; 261.5 & 9.10 \\
\hline & $269.2-506.9$ & 441.5 & $485.2 ; 506.9$ & 67.8 \\
\hline & $506.9-925.0$ & $633.8-710.8$ & $795.4 ; 910.8$ & 22.0 \\
\hline \multirow{6}{*}{$\mathrm{P} 4$} & $25.0-140.8$ & 64.6 & 64.6 & 2.20 \\
\hline & & & 186.2 & fusion \\
\hline & $140.8-270.8$ & 253.8 & 252.4 exo & 10.00 \\
\hline & $270.8-369.2$ & 338.5 & 318.5 & 37.6 \\
\hline & $369.2-525.0$ & 443.1 & $457.9 ; 475.0$ & 25.2 \\
\hline & $525.0-1000.0$ & - & 823.1 & 11.2 \\
\hline
\end{tabular}

For all compounds, the DSC curve has an endothermic peak corresponding to the temperature range $184.6-187.7^{\circ} \mathrm{C}$. These melting point values are consistent with the literature values of $185-188^{\circ} \mathrm{C}$. These values and the accuracy of melting peaks indicate a high purity of the studied compounds. For I-AS the melting process is followed by decomposition, which takes place in four steps and the loss of mass is practically complete $(\Delta \mathrm{m}=100 \%)$. The second and third decomposition stages are difficult to delimit on the TG and even DTG, DSC curves. The decomposition process, a complex one, is accompanied by endothermic but also exothermic effects.

According to thermal curves and thermoanalytic data (Table I), I-AS has a relatively high thermal stability. Compared to I-AS, the pharmaceutical compounds (drugs) show less thermal stability. This is due to the presence of microcrystalline cellulose, croscarmellose calcium, hydroxypropyl cellulose, lactose monohydrate, crosspovidone, corn starch, magnesium stearate, colloidal $\mathrm{SiO}_{2}$, and their possible interactions with the active substance. The thermal decomposition of these compounds begins before melting.
The thermal behaviour of pharmaceuticals is similar to that of the active substance, but still shows some differences in the nature and number of processes that take place.

Thus, additional decomposition steps arise, particularly in the DTG and DSC curves, through the corresponding peaks. As with the active substance, some of the decomposition steps are difficult to differentiate on the TG curve, especially for the P2 and P4 compounds. The differences that occur in the thermal behaviour, implicitly between the thermo-analytic curves of the four pharmaceutical compounds, are due to their different composition with respect to the excipients in the molecule.

\section{Spectroscopy FT-IR}

In addition to the thermal analysis, FT-IR spectroscopy was also used in this study. It can be said to be the most appropriate technique in the analysis of solid pharmaceutical forms because the substances studied are not subjected to thermal or mechanical changes during the preparation of the samples. In interpreting the results, the emergence of a new absorption band, strip extension (band) and/or intensity change are the main features pursued. 
The main absorption bands $\left(\mathrm{cm}^{-1}\right)$ for the studied compounds

\begin{tabular}{|c|c|c|c|c|c|}
\hline I-AS & $\mathrm{P} 1$ & $\mathrm{P} 2$ & P3 & $\mathrm{P} 4$ & Assignment \\
\hline $3443 w$ & $3379 \mathrm{~m}$ & $3383 \mathrm{~m}$ & $3441 \mathrm{w}-\mathrm{m}$ & $3402 \mathrm{i}$ & $v_{\mathrm{NH}}(\mathrm{N}-\mathrm{H}) ; v_{\mathrm{OH}}(\mathrm{COOH})$ \\
\hline $2961 \mathrm{~m} ; 2872 \mathrm{~m}$ & $2959 \mathrm{~m} ; 2872 \mathrm{~m}$ & $2961 \mathrm{~m} ; 2872 \mathrm{~m}$ & $2959 \mathrm{~m} ; 2872 \mathrm{~m}$ & 2936 m; 2893 m & $v_{\text {asymC-H }}\left(\mathrm{CH}_{3} ; \mathrm{CH}_{2}\right)$ \\
\hline $1732 \mathrm{i}$ & $1732 \mathrm{i}$ & $1732 \mathrm{i}$ & $1732 \mathrm{i}$ & - & $v_{\mathrm{C}=\mathrm{O}}$ \\
\hline $1616 \mathrm{i}$ & $1616 \mathrm{i}$ & $1616 \mathrm{i}$ & $1616 \mathrm{i}$ & $1626 \mathrm{vw}$ & $v_{\mathrm{C}=\mathrm{N}} ; v_{\mathrm{C}=\mathrm{O}} ; v_{\mathrm{N}-\mathrm{H}}$ \\
\hline $\begin{array}{c}1436 \mathrm{~m} ; 1406 \mathrm{~m} \\
1337 \mathrm{~m}\end{array}$ & $\begin{array}{c}1439 \mathrm{~m} ; 1406 \mathrm{~m} ; \\
1339 \mathrm{~m}\end{array}$ & $\begin{array}{c}1439 \mathrm{~m} ; 1406 \mathrm{~m} ; \\
1339 \mathrm{~m}\end{array}$ & $\begin{array}{c}1439 \mathrm{~m} ; 1406 \mathrm{~m} ; \\
1339 \mathrm{~m}\end{array}$ & $\begin{array}{c}1456 \mathrm{~m} ; 1404 \mathrm{~m} ; \\
1331 \mathrm{~m}\end{array}$ & $\begin{array}{c}v_{\mathrm{N}=\mathrm{N}} ; v_{\mathrm{C}-\mathrm{C}} \text { ring; } \\
v_{\text {asymCOO}} ; v_{\mathrm{symCOO}}\end{array}$ \\
\hline $\begin{array}{c}1236 \text { w-m; } 1177 \\
\text { w-m }\end{array}$ & $\begin{array}{c}1236 \text { w-m; } 1173 \\
\text { w-m }\end{array}$ & $\begin{array}{c}1236 \text { w-m; } 1175 \\
\text { w-m }\end{array}$ & $\begin{array}{c}1236 \text { w-m; } 1177 \\
\text { w-m }\end{array}$ & $1177 \mathrm{w}-\mathrm{m}$ & $\begin{array}{c}v_{\text {C-N }} ; \delta_{\text {asymCH }} \mathrm{CH}_{3} ; \mathrm{CH}_{2} ; \mathrm{CH} \\
\delta_{\text {sym }} \mathrm{CH}_{3} ; \mathrm{CH}_{2} ; \mathrm{CH}\end{array}$ \\
\hline $\begin{array}{c}1099 \text { w-m; } 937 \\
\text { w-m }\end{array}$ & $1094 \mathrm{~m} ; 1065 \mathrm{~m}$ & $1096 \mathrm{~m} ; 1067 \mathrm{~m}$ & 1099 m; $935 \mathrm{~m}$ & $1074 \mathrm{i} ; 891 \mathrm{w}-\mathrm{m}$ & $\begin{array}{l}v_{\mathrm{C}-\mathrm{O}} ; v_{\mathrm{C}-\mathrm{C}-\mathrm{O}} \text {; in p. C-H } \\
\text { bend; o.p. C-H bend }\end{array}$ \\
\hline $\begin{array}{c}860 \mathrm{w} ; 816 \mathrm{w} \\
781 \mathrm{w}-\mathrm{m} ; 756 \mathrm{~m}\end{array}$ & $779 \mathrm{~m} ; 756 \mathrm{~m}$ & 779 w-m; 756 m & $\begin{array}{c}858 \mathrm{w}-\mathrm{m} ; 816 \mathrm{w}-\mathrm{m} \\
781 \mathrm{~m} ; 756 \mathrm{~m}\end{array}$ & $760 \mathrm{~m}$ & $v_{\text {Si-O }}$ o.p. C-H (ring) \\
\hline $664 \mathrm{w}-\mathrm{m} ; 627 \mathrm{w}-\mathrm{m}$ & $665 \mathrm{~m} ; 629 \mathrm{~m}$ & $665 \mathrm{w} ; 629 \mathrm{w}$ & $664 \mathrm{~m} ; 629 \mathrm{~m}$ & $700 \mathrm{~m} ; 617 \mathrm{~m}$ & $\begin{array}{l}\text { o.p. (ring) } \mathrm{C}=\mathrm{C} \text { bend } \\
\text { o.p. } \mathrm{N}-\mathrm{H} \text { bend } \\
\text { o.p. } \mathrm{O}-\mathrm{H} \text { bend }\end{array}$ \\
\hline $521 \mathrm{w}-\mathrm{m}$ & $521 \mathrm{~m}$ & $521 \mathrm{vw}$ & $521 \mathrm{~m}$ & $534 \mathrm{~m}$ & $\begin{array}{l}\text { o.p. C-H benzene } \\
\text { substituted }\end{array}$ \\
\hline
\end{tabular}

The FT-IR spectra are presented in Figure 6 and the main absorption bands are summarized in Table II.

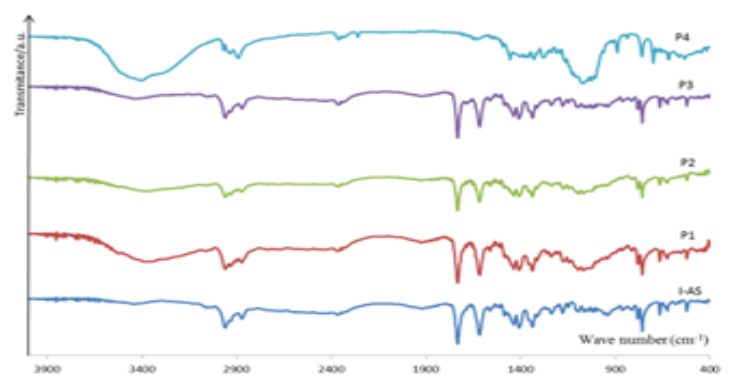

Figure 6.

FT-IR spectra for the studied samples

The main differences resulted after comparing the spectrum of I-AS with the spectra of P1, P2, P3 and $\mathrm{P} 4$ are presented below, as follows.

The considerable broadening and the significant increase ( $\approx 35 \%$ for $\mathrm{P} 1 ; \approx 15 \%$ for $\mathrm{P} 2 ; \approx 7 \%$ for $\mathrm{P} 3$ and $\approx 65 \%$ for P4) of the bands from the region 3650 - 3300 $\mathrm{cm}^{-1}$, attributed to the $\mathrm{NH}$ group present in the all compounds, but especially to the $\mathrm{OH}$ group present in the excipients: starch, microcrystalline cellulose, lactose monohydrate, croscarmellose.

For the two bands of absorption from the region $3000-2200 \mathrm{~cm}^{-1}$ that correspond to the methylene, respectively methyl group from I-AS as well as the excipients: microcrystalline cellulose, lactose monohydrate, croscarmellose, crospovidone, magnesium stearate, the following situations are encountered: (a) the increase of the intensity for the two bands with $\approx 15 \%$, respectively $20 \%$ for $\mathrm{P} 1$; (b) the decrease of the intensity for the two bands with $\approx 15 \%$ for $\mathrm{P} 2$; (c) the maintaining of the intensity for the two bands in the case of P3; (d) the decrease of the intensity of the band from $2936 \mathrm{~cm}^{-1}$ with $20 \%$, respectively the increase of the intensity of the band from $2893 \mathrm{~cm}^{-1}$ with $\approx 10 \%$ for $\mathrm{P} 4$ (practically, there is a reversal of the intensity of the two bands).

For the most intense band $\left(1732 \mathrm{~cm}^{-1}\right)$ which represents the carbonyl vibration band from I-AS as well as the excipients: crospovidone and magnesium stearate, the intensity increases for $\mathrm{P} 1(\approx 15 \%)$ and $\mathrm{P} 3(\approx 10 \%)$ and decreases for $\mathrm{P} 2(\approx 12 \%)$, while for the $\mathrm{P} 4$ disappears. The increase $\left(\approx 10 \%\right.$ for P1) of the band $1616 \mathrm{~cm}^{-1}$ with one shoulder at $1560 \mathrm{~cm}^{-1}$, respectively the decrease $(\approx 15 \%$ for $\mathrm{P} 2$ ) of the same band which represents the vibrations of the groups $\mathrm{C}=\mathrm{N}$ and $\mathrm{C}=\mathrm{C}$ from $\mathrm{I}$ $\mathrm{AS}$ as well as the excipients: crospovidone. For the P4 samples the band disappears and appears one band at $1626 \mathrm{~cm}^{-1}$ of weakly intensity $(\approx 8 \%)$. For P3 the intensity remains constant.

For the bands of absorption from the region 1500 $1300 \mathrm{~cm}^{-1}$ that corresponds to the $\mathrm{N}=\mathrm{N}, \quad \mathrm{C}-\mathrm{C}$ ring stretching vibrations from I-AS, respectively to asym and sym $\mathrm{COO}$ vibrations from magnesium stearate, the following situations are encountered: (a) the change of place of the band from $1436 \mathrm{~cm}^{-1}$ to $1456 \mathrm{~cm}^{-1}$ in $\mathrm{P} 4$ and the maintaining of the intensity; (b) the appearance of one new band in P4 at $1362 \mathrm{~cm}^{-1}$ with the intensity $\approx 33 \%$; (c) the disappearance of the shoulder from $1483 \mathrm{~cm}^{-1}$ in P1, P2 and P3; (d) the increases of the intensity for the three bands: from $1436 \mathrm{~cm}^{-1}$ with $\approx 20 \%$ for $\mathrm{P} 1$; $\approx 5 \%$ for $\mathrm{P} 3$; from $1406 \mathrm{~cm}^{-1}$ with $\approx 12 \%$ for $\mathrm{P} 1$; from $1338 \mathrm{~cm}^{-1}$ with $\approx 15 \%$; (e) the decreases of the intensity for the three bands: from $1436 \mathrm{~cm}^{-1}$ with $\approx$ $8 \%$ for $\mathrm{P} 1$; from $1406 \mathrm{~cm}^{-1}$ with $\approx 20 \%$ for $\mathrm{P} 2 ; \approx$ $6 \%$ for $\mathrm{P} 3 ; \approx 15 \%$ for $\mathrm{P} 4$; from $1338 \mathrm{~cm}^{-1}$ with $\approx$ $12 \%$ for $\mathrm{P} 2 ; \approx 8 \%$ for $\mathrm{P} 4$; (f) the maintaining of the intensity for the two bands: from $1436 \mathrm{~cm}^{-1}$ in the case of $\mathrm{P} 4$; from $1338 \mathrm{~cm}^{-1}$ in the case of $\mathrm{P} 3$ and $\mathrm{P} 1$. 
For the two bands of absorption from 1236, respectively $1177 \mathrm{~cm}^{-1}$, that correspond to the $\mathrm{C}-\mathrm{N}$, respectively to asym. and sym. $\mathrm{CH}_{3}, \mathrm{CH}_{2}, \mathrm{CH}$ vibrations the intensity increases with $\approx 15 \%$, respectively with $\approx 25 \%$ for $\mathrm{P} 1$; - the intensity decreases with $\approx 5 \%$ for $\mathrm{P} 2$; - for $\mathrm{P} 3$, the intensity of the first band remains constant, respectively increases with $\approx 5 \%$ for the second band; - for $\mathrm{P} 4$, the second band disappear while the first band it's moving at $1277 \mathrm{~cm}^{-1}$ and the intensity of the band increases with $\approx 20 \%$.

For the bands of absorption from 1099 and $937 \mathrm{~cm}^{-}$ 1 in I-AS, which correspond to the $\mathrm{C}-\mathrm{O}$ (C-C-O) vibrations, respectively in p. band and o.p. $\mathrm{C}-\mathrm{H}$ band it comes out that: (a) for P4 appears one band relatively broad $\left(1175-875 \mathrm{~cm}^{-1}\right)$ with one maximum at $1074 \mathrm{~cm}^{-1}$ and the intensity of $75 \%$, accompanied by one shoulder (the intensity $\approx 60 \%$ ) at $1024 \mathrm{~cm}^{-1}$ and one band at $891 \mathrm{~cm}^{-1}$ with the intensity of $\approx 22 \%$; (b) the appearance of one new band with shoulder for $\mathrm{P} 1$ and $\mathrm{P} 2$ at $1065 \mathrm{~cm}^{-1}$, respectively $1038 \mathrm{~cm}^{-1}$; (c) the disappearance of the band from $937 \mathrm{~cm}^{-1}$ for I-AS, P1 and P2; (d) the increases of the intensity of the band of absorption from $1099 \mathrm{~cm}^{-1}$ in $\mathrm{I}-\mathrm{AS}$ with $\approx 35 \%$ for $\mathrm{P} 1, \approx 10 \%$ for $\mathrm{P} 2$ and $\mathrm{P} 3$.

For the bands of absorption from the region 860 $750 \mathrm{~cm}^{-1}$ which correspond to the o. p. C-H (ring) o.p. C-H band and Si-O vibrations from I-AS and excipients it comes out that: (a) the bands from 860 and $816 \mathrm{~cm}^{-1}$ disappear for P1, P2 and P4, while in P4 disappears the band from $781 \mathrm{~cm}^{-1}$; (b) the intensity of the bands from 860 and $816 \mathrm{~cm}^{-1}$ increases with $\approx 5 \%$ for $\mathrm{P} 3$; (c) the intensity of the bands from 781 and $756 \mathrm{~cm}^{-1}$ increases with $\approx 20 \%$ for P1 and decreases with $10 \%$, respectively $15 \%$ for $\mathrm{P} 2$ and with $10 \%$ for $\mathrm{P} 4$; (d) for P3 the intensity of the two bands remains constant.

The two bands from 664 and $627 \mathrm{~cm}^{-1}$ on displace at 700 respectively $617 \mathrm{~cm}^{-1}$ in $\mathrm{P} 4$, while the intensity increases with $\approx 25 \%$; - for the same bands, the intensity increases with $\approx 20 \%$ for P1 and with $\approx 5 \%$ for $\mathrm{P} 3$, while for $\mathrm{P} 2$ the intensity decreases with $\approx 5 \%$.

The band from $521 \mathrm{~cm}^{-1}$ which corresponds to the vibrations of o.p. C-H benzene substituted on displaces at $534 \mathrm{~cm}^{-1}$ in the case of $\mathrm{P} 4$; - the intensity of the band mentioned previously increases with $\approx 17 \%$ for $\mathrm{P} 1$, with $\approx 7 \%$ for $\mathrm{P} 3$ and with $\approx 25 \%$ for $\mathrm{P} 4$.

On the basis of the mentioned differences it may be considered that the composition of the studied compounds is different.

From the FT-IR spectra and wave number where characteristic bands appear, the active substance and its pharmaceutical forms can be easily differentiated.

$X$-ray analysis

In addition to thermal analysis and FT-IR spectroscopy, X-ray powder diffraction (XRPD) was also used to confirm the possible interaction of irbesartan with different excipients. The X-ray diffraction patterns of the irbesartan, P1, P2, P3 and P4 are shown in Figure 7.

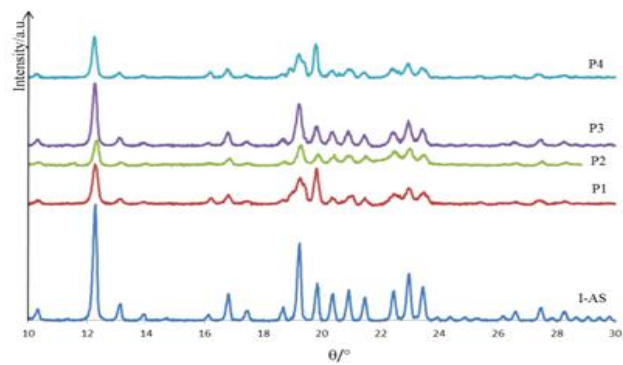

Figure 7.

X-ray diffractograms of irbesartan and of the pharmaceutical products

By the comparing of the diffractogram of irbesartan with the diffractograms of the pharmaceutical products several differences of the studied compounds were registered.

The X-ray diffraction data for the studied compounds are presented in Table III.

Table III

X-ray diffraction data for irbesartan and the pharmaceutical compounds

\begin{tabular}{|c|c|}
\hline \multicolumn{2}{|c|}{ Irbesartan } \\
\hline 2 teta & $\mathrm{I} \%$ \\
\hline 12.29 & 100 \\
\hline 13.13 & 14.18 \\
\hline & \\
\hline 16.81 & 22.81 \\
\hline 19.22 & 64.80 \\
\hline 19.84 & 31.78 \\
\hline 20.38 & 22.88 \\
\hline 20.91 & 26.16 \\
\hline 21.46 & 18.72 \\
\hline 22.46 & 25.25 \\
\hline 22.97 & 40.28 \\
\hline 23.45 & 29.00 \\
\hline
\end{tabular}

\begin{tabular}{|c|c|}
\hline \multicolumn{2}{|c|}{ P1 } \\
\hline 2teta & $\mathrm{I} \%$ \\
\hline 12.27 & 100 \\
\hline 13.05 & 10.25 \\
\hline 16.25 & 14.93 \\
\hline 16.82 & 22.96 \\
\hline 19.26 & 65.49 \\
\hline 19.81 & 87.99 \\
\hline 20.36 & 16,23 \\
\hline 20.98 & 20.18 \\
\hline 21.47 & 15.23 \\
\hline 22.44 & 24.52 \\
\hline 22.95 & 39.34 \\
\hline 23.49 & 29.09 \\
\hline
\end{tabular}

\begin{tabular}{|c|c|}
\hline \multicolumn{2}{|c|}{ P4 } \\
\hline 2teta & $\mathrm{I} \%$ \\
\hline 12.34 & 100 \\
\hline 13.14 & 11.67 \\
\hline 16.19 & 10.40 \\
\hline 16.87 & 27.91 \\
\hline 19.28 & 82.50 \\
\hline 19.88 & 45.86 \\
\hline 20.42 & 42.78 \\
\hline 20.91 & 39.60 \\
\hline 21.48 & 38.55 \\
\hline 22.44 & 57.27 \\
\hline 22.98 & 68.76 \\
\hline 23.49 & 42.92 \\
\hline
\end{tabular}

\begin{tabular}{|c|c|}
\hline \multicolumn{2}{|c|}{ P3 } \\
\hline 2teta & $\mathrm{I} \%$ \\
\hline 12.28 & 100 \\
\hline 13.09 & 13.17 \\
\hline & \\
\hline 16.79 & 21.52 \\
\hline 19.21 & 66.66 \\
\hline 19.83 & 31.38 \\
\hline 20.38 & 22.44 \\
\hline 20.90 & 23.59 \\
\hline 21.46 & 17.30 \\
\hline 22.41 & 21.59 \\
\hline 22.95 & 39.57 \\
\hline 23.41 & 26.33 \\
\hline
\end{tabular}

\begin{tabular}{|c|c|}
\hline \multicolumn{2}{|c|}{ P2 } \\
\hline 2 teta & $\mathrm{I} \%$ \\
\hline 12.26 & 100 \\
\hline 13.06 & 11.83 \\
\hline 16.18 & 13.52 \\
\hline 16.78 & 20.85 \\
\hline 19.22 & 57.21 \\
\hline 19.78 & 81.51 \\
\hline 20.38 & 18.32 \\
\hline 20.89 & 21.96 \\
\hline 21.44 & 12.73 \\
\hline 22.39 & 22.79 \\
\hline 22.94 & 35.51 \\
\hline 23.43 & 23.52 \\
\hline
\end{tabular}


According to the data presented in Table III, it can be concluded that there are differences between the data corresponding to the $\mathrm{P} 1, \mathrm{P} 2$ and $\mathrm{P} 4$ diffractograms, respectively the change in the intensity for the majority of the lines present in the diffractogram of the active substance irbesartan, with the displacement of these lines to values lower or higher than $2 \theta$.

\section{Conclusions}

The irbesartan - active substance (I-AS) and four of the pharmaceutical products correspondents: P1, P2, P3 and P4 were simultaneously characterized by thermal analysis, FT-IR spectroscopy and X-ray diffraction patterns.

Excipients are very important components in drug formulation, they can influence positively or negatively the characteristics of commercially pharmaceutical products. Based on that, it is really important to study all the possible interactions between the active substance and all the excipients used in drug formulation.

From the thermoanalytic curves that showed significant differences between the curves of the pure compound and those of the pharmaceuticals, as well as the FT-IR spectra and X-ray diffractograms, it can be concluded that there is a different behaviour between irbesartan - the active substance, and the pharmaceutical forms, corresponding to the possible interactions between the active substance and excipients.

\section{References}

1. Buda V, Andor M, Cristescu C, Voicu M, Suciu L, Muntean C, Cretu O, Baibata D, Gheorghiu CM, Tomescu MC, The influence of perindopril on PTX3 plasma levels in hypertensive patients with endothelial dysfunction. Farmacia, 2016; 64(3): 382-389.

2. Bolourchian N, Fashami FM, Foroutan SM, Irbesartan dissolution enhancement using PEG-based solid dispersions: The effect of PEG molecular weights. Farmacia, 2017; 65(4): 537-544.

3. Burcea Dragomiroiu GTA, Ginghina O, Miron DS, Barca M, Popa DE, Hirjau M, Lupuleasa D, Radulescu FS, The influence of splitting on the in vitro release of metoprolol succinate from scored tablets. Farmacia, 2015; 63(2): 280-285.

4. Ceker Z, Takmaz SA, Baltaci B, Basar H, The effect of esmolol on corrected-QT interval, corrected-QT interval dispersion changes seen during anesthesia induction in hypertensive patients taking an angiotensin-converting enzyme inhibitor. Rev Bras Anestesiol., 2015; 65(1): 34-40.

5. $* * *$, European Pharmacopoeia, $9^{\text {th }}$ Edition, Council of Europe, Strasbourg, 2017.

6. ***, Farmacopeea Româna, Ed. a X-a, Editura Medicala, Bucharest, 2008, (available in Romanian).
7. Fita CA, Lupuliasa D, Hirjau V, Sala G, Karampelas O, Saramet G, The influence of formulation factors on the release of the metoprolol tartrate from extended release tablets. Farmacia, 2012; 60(6): 905-914.

8. Frunza M, Lisa G, Zonda R, Popa MI, Intercalation of Ketoprofen into $\mathrm{Mg}$-Al hydrotalcites. Synthesis and characterization. Rev Chim (Bucharest), 2008; 59(4): 409-412.

9. Fry CH, Gray RP, Dhillon PS, Jabr RI, Dupont E, Patel PM, Peters NS, Architectural correlates of myocardial conduction: changes to the topography of cellular coupling, intracellular conductance, and action potential propagation with hypertrophy in Guinea-pig ventricular myocardium. Circ Arrhythm Electrophysiol., 2014; 7(6): 1198-1204.

10. Fuliaş A, Tita B, Bandur G, Tita D, Thermal decomposition of some benzodiazepines under non-isothermal conditions. Kinetic study. Rev Chim (Bucharest), 2009; 60(10): 1079-1083.

11. Giron D, Mutz M, Garnier S, Solid-state of pharmaceutical compounds. J Therm Anal Cal., 2004; 77: 709-747.

12. Grall S, Biere L, Le Nezet M, Bouvier JM, LucasChauvelon P, Richard C, Abi-Khalil W, Delepine S, Prunier F, Furber A, Relationship between betablocker and angiotensin-converting enzyme inhibitor dose and clinical outcome following acute myocardial infarction. Circ J., 2015; 79(3): 632-640.

13. Howell BA, Ray JA, Comparison of isothermal and dynamic methods for the determinationof activation energy by thermogravimetry. $J$ Therm Anal Cal., 2006; 83: 63-66.

14. Howell BA, Utility of kinetic analysis in the determination of reaction mechanism. $J$ Therm Anal Cal., 2006; 85: 165-167.

15. Ndlebe VJ, Brown ME, Glas BD, The thermal stability of triprolidine hydrochloride and its mixtures with cyclodextrin and glucose. $J$ Therm Anal Cal., 2004; 77: 445-457.

16. Smith AH, Flack EC, Borgman KY, Owen JP, Fish FA, Bichell DP, Kannankeril PJ, A common angiotensin-converting enzyme polymorphism and preoperative angiotensin-converting enzyme inhibition modify risk of tachyarrhythmias after congenital heart surgery. Heart Rhythm., 2014; 11(4): 637-643.

17. Suciu L, Cristescu C, Tomescu M, Balas M, Muresan R, Vlaia V, Voicu M, Suciu M, Gradinaru R, Vlaia L, Draganescu D, The impact of hypertension and associated comorbidities on quality of life assessment questionnaire SF-36 V2. Farmacia, 2013; 61(3): 503-517.

18. Tanaka H, Brown ME, The theory and practice of thermoanalytical kinetics of solid-state reactions. $J$ Therm Anal Cal., 2005; 80: 795-797.

19. Țica OA, Țica O, Antal L, Hatos A, Popescu MI, Pantea Stoian A, Bratu OG, Găman MA, Piţuru SM, Diaconu CC, Modern oral anticoagulant treatment in patients with atrial fibrillation and heart failure: insights from the clinical practice. Farmacia, 2018; 66(6): 972-976.

20. Tita B, Fuliaş A Marian E, Tita D, Thermal behaviour of acetylsalicylic acid - active substance 
and tablets. Kinetic study under non-isothermal conditions. Rev Chim (Bucharest), 2009; 60(4): 419-423.

21. Tita B, Stefanescu M, Tita D, Complexes of the anti-inflamatory non-steroidal drugs from oxicam family. 1. Synthesis and characterization of the $\mathrm{Zn}$ (II) complex with piroxicam. Rev Chim (Bucharest), 2011; 62(10): 1002-1007.

22. Tita B, Fuliaş A, Stefanescu M, Marian E, Tita D, Kinetic study of decomposition of ibuprofen under isothermal conditions. Rev Chim (Bucharest), 2011; 62(2): 216-221.

23. Tita D, Fuliaș A, Tita B, Thermal stability of ketoprofen Part 2. Kinetic study of the active substance under isothermal conditions. $J$ Therm Anal Calorim., 2013; 111: 1979-1985.
24. Tita D, Jurca $\mathrm{T}$, Tita B, Thermal stability of pentoxifylline: active substance and tablets. Part 1 . Kinetic study of the active substance under nonisothermal conditions. $J$ Therm Anal Calorim., 2013; 111: 291-299.

25. Wu T, Wu D, Wu Q, Zou B, Huang X, Cheng X, $\mathrm{Wu} \mathrm{Y}$, Hong K, Li P, Effect and mechanism of Irbesartan on occurrence of ventricular arrhythmias in rats with myocardial ischemia through connexin43 (Cx43). As Pac J Trop Med., 2016; 9(10): 1007-1012.

26. Xu F, Sun LX, Tan ZC, Liang JG, Zhang T, Adiabatic calorimetry and thermal analysis on acetaminophen. J Therm Anal Cal., 2006; 83: 187-191. 